\title{
Seroprevalence of hepatitis $E$ virus in pregnant women in northern Lebanon
}

Mohamad Bashar Ismail,, Safaa Khodor, ${ }^{2}$ Marwan Osman, ${ }^{1}$ Hassan Mallat, ${ }^{1}$ Fouad Dabboussi ${ }^{1}$ and Monzer Hamze ${ }^{1}$

${ }^{1}$ Health and Environment Microbiology Laboratory, Doctoral School of Sciences and Technology, Faculty of Public Health, Lebanese University, Tripoli, Lebanon (Correspondence to: Monzer Hamze: mhamze@monzerhamze.com). ${ }^{2}$ Faculty of Public Health, Lebanese University, Tripoli, Lebanon.

\begin{abstract}
Background: Hepatitis E virus is the main cause of acute hepatitis globally. Infection is especially serious in pregnant women in whom the death rate can reach $25 \%$. The prevalence of hepatitis E virus in pregnant women in Lebanon is not known.
\end{abstract}

Aims: This study aimed to investigate the seroprevalence of hepatitis E virus infection in a sample of pregnant women in northern Lebanon.

Methods: A total of 450 pregnant women from Tripoli, North Lebanon were enrolled in the study. Sera were tested for the presence of anti-hepatitis E virus IgG antibodies using an ELISA technique. Information was collected on the sociodemographic characteristics of the women and their risk factors for hepatitis E virus infection (drinking-water source, blood transfusion and contact with animals).

Results: Only one woman was positive for hepatitis E virus giving a prevalence of $0.22 \%$. She had good living conditions, socioeconomic status and educational level and reported no exposure to any risk factors associated with hepatitis $\mathrm{E}$ virus infection. Most of the women (87.3\%) had a medium or high income level, $47.1 \%$ had a university education and $64.9 \%$ drank bottled water. Only a small proportion were exposed to risk factors for hepatitis E virus infection: $14.7 \%$ had direct contact with animals and $3.8 \%$ had had a blood transfusion.

Conclusion: The prevalence of hepatitis E virus infection in the sample was low $(0.22 \%)$. However, further epidemiological studies among other population groups are required to determine the national prevalence of hepatitis E virus in Lebanon.

Keywords: hepatitis E virus, prevalence, pregnancy, Lebanon

Citation: Ismail MB; Khodor S; Osman M; Mallat H; Dabboussi F; Hamze M. Seroprevalence of hepatitis E virus in pregnant women in northern Lebanon. East Mediterr Health J. 2020;26(5):580-585. https://doi.org/10.26719/emhj.19.103

Received: 18/08/16; accepted: 04/06/18

Copyright (c) World Health Organization (WHO) 2020. Open Access. Some rights reserved. This work is available under the CC BY-NC-SA 3.0 IGO license (https://creativecommons.org/licenses/by-nc-sa/3.o/igo).

\section{Introduction}

Five forms of human viral hepatitis are known. Among them, hepatitis E virus is the most common cause of acute viral hepatitis and jaundice worldwide (1). Globally, it is estimated that about 20 million hepatitis E infections occur every year, with more than three million symptomatic cases and about 44000 hepatitis E-related deaths (2).

Hepatitis E virus belongs to the genus Hepevirus within the family Hepeviridae. A single hepatitis E virus serotype and four major genotypes (HEV1, HEV2, HEV 3 and HEV4) have been described $(3,4)$. Although these four genotypes are able to infect humans, they show different epidemiological patterns depending on their geographical distribution (1). In developing countries, HEV1 and HEV2, which are associated with faecal-oral transmission and waterborne spread, cause numerous sporadic cases and outbreaks. $\mathrm{HEV}_{3}$ and $\mathrm{HEV}_{4}$ are common in several animal reservoirs; they are transmitted to humans through zoonotic foodborne routes and cause sporadic cases of increasing importance (1,5-7).

Unsafe water supplies, poor hygiene, overcrowded living conditions, young adult age and close contact with animals, especially pigs, are risk factors for hepatitis E infection. Hepatitis E infection is generally an acute, self-limiting disease; however, in some cases, it can cause acute liver failure or chronic liver disease $(8,9)$. In pregnant women, hepatitis $\mathrm{E}$ infection can cause serious illness characterized by frequent occurrence of fulminant hepatitis $(10,11)$ with a high mortality rate, which is 10-fold higher than the mortality rate in men or non-pregnant women (12).

Hepatitis E infection can be detected using serological assays of anti-hepatitis $E$ virus immunoglobulin $M$ (IgM) and IgG in patient sera, mostly by enzymelinked immunosorbent assays (ELISA) (11,13). IgM antibodies decrease in the weeks following infection and subsequently are rarely detectable and even absent in most studies of hepatitis $\mathrm{E}$ virus seroprevalence. In contrast, detectable levels of anti-hepatitis $\mathrm{E}$ virus IgG may persist for years after infection (11,13). These antibodies are therefore widely used to evaluate the prevalence of the virus in various populations including asymptomatic pregnant women (11).

In Lebanon, the prevalence of anti-hepatitis $\mathrm{E}$ virus IgG antibodies has been investigated in only one study of blood donors and the results showed $4 \%$ positivity (14). 
However, the prevalence in pregnant Lebanese women has never been studied. Therefore, the aim of our study was to investigate the prevalence of hepatitis $\mathrm{E}$ virus infection in pregnant women in Tripoli, the main city of the North Lebanon governorate.

\section{Methods}

\section{Study design and participants}

This was a cross-sectional study conducted during a 5-month period (April to August 2015) in Tripoli in northern Lebanon.

The sample size was determined using the single population proportion formula: $N=z^{2} p(1-p) / w^{2}$, where $z=$ standard normal distribution value at $95 \%$ confidence level which is equal to $1.96, p=$ the expected prevalence of hepatitis $\mathrm{E}$ virus in pregnant women and $w=$ the margin of error, taken as $4 \%$. As the prevalence of hepatitis $E$ virus in pregnant women in Lebanon was not known, we used the highest prevalence (12.7\%) reported from Turkey, a neighbouring country (15). Based on these parameters, the calculated minimum sample size was 267. Tripoli was divided into four geographical regions. From each region, one health facility of 19 attended by pregnant women was randomly selected. A trained nurse of the antenatal unit of the facility explained the purpose of the study to the potential participant, obtained her consent, filled the questionnaire with the participant and then collected the blood sample. In total, 450 women were enrolled in this study, representing all the pregnant women attending the selected health facilities during the study period. Non-Lebanese pregnant women were excluded from the study.

\section{Data collection}

The women were surveyed using a questionnaire which included the known risk factors for hepatitis $\mathrm{E}$ virus infection (drinking water source, blood transfusion, sociodemographic and contact with animals), pregnancy stage, sociodemographic characteristics (age, education level and income level). The minimum wage (675 000 Lebanese pounds; US\$450) was used to classify the income level. Families with a monthly income below the minimum wage were classified as low income. Families with a monthly income ranging from the minimum wage to twice the minimum wage were classified as middle income. Families with a monthly income more than twice the minimum wage were considered high income

\section{Serological tests}

Three millilitres $(3 \mathrm{~mL})$ of venous blood were collected into a clot activator tube by venepuncture. Sera were separated immediately and kept frozen at $-20^{\circ} \mathrm{C}$ until tested. The presence of anti-hepatitis $\mathrm{E}$ virus IgG antibodies was examined using an ELISA kit (Euroimmun, Lübeck, Germany) following the manufacturer's instructions. According to the manufacturer, tests performed with this assay have a specificity and sensitivity of $100 \%$.

\section{Data analysis}

Data were analysed using GraphPad Prism 6 software. Quantitative data are presented as mean and standard deviation (SD); categorical data are presented as frequencies.

\section{Ethical considerations}

Ethical approval for the study was obtained from ethics committee of the Azm Center for Research in Biotechnology and Its Applications, Lebanese University. Informed consent was obtained from each participant included in the study. Written consent was obtained from each literate participant. In the case of illiterate participants, the nurse explained the purpose of the study to the woman and a literate witness (another health care worker or a person accompanying the woman). If the illiterate women agreed to participate by giving her verbal consent, the literate witness signed on her behalf.

\section{Results}

A total of 450 pregnant women participated in the study. The age range of the participants was $15-43$ years, with a mean age of 28.33 (SD 5.82) years. None of the participants had clinical symptoms associated with hepatitis $\mathrm{E}$ virus infection at the time of sample collection. Anti-hepatitis $\mathrm{E}$ virus IgG antibodies were found in only one participant (0.2\%). She had good living conditions, socioeconomic status and educational level and reported no exposure to any of the risk factors associated with hepatitis $\mathrm{E}$ virus infection. Most of the women in the study had a medium $(46.4 \%)$ or high (40.9\%) income level, about half (47.1\%) had a university education and two thirds (64.9\%) drank bottled water (Table 1). Only a small proportion were exposed to the risk factors associated with hepatitis E virus infection: $14.7 \%$ had direct contact with animals and $3.8 \%$ had had a blood transfusion.

\section{Discussion}

To the best of our knowledge, our study is the first to determine the seroprevalence of anti-hepatitis E virus IgG antibodies in pregnant women in Lebanon. Our results revealed a very low prevalence of hepatitis E virus (0.22\%). This prevalence was the lowest reported in other Mediterranean countries for the same group (Table 2). These data may reflect limited circulation potential of this virus in Lebanese pregnant women.

The status of hepatitis $\mathrm{E}$ virus infection has been reported in several countries of the Eastern Mediterranean Region including Egypt, Islamic Republic of Iran, Iraq, Saudi Arabia, Tunisia and United Arab Emirates (26). In these countries, numerous studies have been performed in different populations including blood donors, pregnant women, hepatitis patients and haemodialysis patients. In contrast, the prevalence of hepatitis $\mathrm{E}$ virus and its associated disease in Lebanon is largely unknown and epidemiological data are limited to a single study of seroprevalence performed on 100 blood donors in 1998 which showed a low prevalence (4\% of positivity) (14). 


\begin{tabular}{|c|c|c|}
\hline \multicolumn{3}{|c|}{$\begin{array}{l}\text { Table } 1 \text { Demographic characteristics of the sample of } \\
\text { pregnant women in Tripoli, Lebanon and risk factors for } \\
\text { hepatitis E virus infection }\end{array}$} \\
\hline Variable & No. $(n=450)$ & $\%$ \\
\hline \multicolumn{3}{|l|}{ Age group (years) } \\
\hline$\leq 25$ & 158 & 35.1 \\
\hline $26-34$ & 212 & 47.1 \\
\hline$\geq 35$ & 80 & 17.8 \\
\hline \multicolumn{3}{|l|}{ Pregnancy trimester } \\
\hline First & 111 & 24.7 \\
\hline Second & 145 & 32.2 \\
\hline Third & 194 & 43.1 \\
\hline \multicolumn{3}{|l|}{ Educational level } \\
\hline Illiterate & 9 & 2 \\
\hline Primary school & 41 & 9.1 \\
\hline Middle school & 107 & 23.8 \\
\hline Secondary school & 81 & 18 \\
\hline University & 212 & 47.1 \\
\hline \multicolumn{3}{|l|}{ Income level } \\
\hline Low & 57 & 12.7 \\
\hline Medium & 209 & 46.4 \\
\hline High & 184 & 40.9 \\
\hline \multicolumn{3}{|l|}{ Contact with animals } \\
\hline Yes & 66 & 14.7 \\
\hline No & 384 & 85.3 \\
\hline \multicolumn{3}{|l|}{ Blood transfusion } \\
\hline Yes & 17 & 3.8 \\
\hline No & 433 & 96.2 \\
\hline \multicolumn{3}{|l|}{ Drinking water source } \\
\hline Bottled water & 292 & 64.9 \\
\hline Tap water & 111 & 24.7 \\
\hline Spring and well water & 47 & 10.4 \\
\hline
\end{tabular}

Several studies have obtained similar results to ours showing a low prevalence of hepatitis $\mathrm{E}$ virus infection in pregnant women: $0.4 \%$ in El Paso, United States of America (27), $1 \%$ in Rio de Janeiro, Brazil (28), $1.6 \%$ in Ciudad Juarez, Mexico (27) and 1.6\% in Caracas, Venezuela (29). Importantly, even in endemic countries with suspected outbreaks of hepatitis Evirus infection such as the Islamic Republic of Iran, a relatively low prevalence of hepatitis E virus $(3.6 \%)$ was reported in pregnant women $(30)$. In Lebanon, no hepatitis E virus outbreaks have occurred and the country is not considered endemic for the disease. Our data differ from those of other studies that examined pregnant women which showed a high prevalence of hepatitis E virus: $58.6 \%$ in Dakahlya Governorate, Egypt (21) and $28.8 \%$ in Rajasthan, India (31). Such discrepancies in hepatitis $\mathrm{E}$ virus prevalence in pregnant women in different countries are not surprising because even in the same country, considerable epidemiological differences exist. For example, a study in France in pregnant women showed a higher seroprevalence of hepatitis $\mathrm{E}$ virus in the south $(29.3 \%)$ than in the north of the country $(3.6 \%)$ (22). Changes of hepatitis $\mathrm{E}$ virus prevalence in different regions and countries may be explained, in part, by sociodemographic and sanitation differences.

Our study in pregnant women showed an even lower prevalence of hepatitis $\mathrm{E}$ virus (0.22\%) than in Lebanese blood donors (4\%) (14). In addition to differences in geographical area and population group examined, this difference may, to some extent, be due to sanitation and hygiene improvements in the country between 1998 and 2015. Progressive improvements of sanitation conditions, provision and wide use of filtered and bottled water, and organization of effective food safety campaigns may effectively reduce the faecal-oral transmission and waterborne spread of hepatitis $\mathrm{E}$ virus, which are the main modes of transmission of this virus in developing regions. Such improvements are therefore important to

\begin{tabular}{|c|c|c|c|c|}
\hline Country & Sample size & $\%$ positive & Kit manufacturer & Year (reference) \\
\hline \multirow[t]{2}{*}{ Turkey } & 245 & 12.6 (IgG); o (IgM) & Virotech GmbH, Germany & $2004(15)$ \\
\hline & 386 & $7(\operatorname{IgG})$ & Globe Diagnostics, Italy & $2006(16)$ \\
\hline \multirow[t]{3}{*}{ Spain } & 424 & $0.94(\operatorname{IgG})$ & Abbott Diagnostics, United States of America & $2004(17)$ \\
\hline & 1517 & 5.45 (IgG); o (IgM) & Biokit, Spain & $2010(18)$ \\
\hline & 1040 & $3.6(\operatorname{IgG}) ; 0.67$ (IgM) & DiaPro Diagnostic Bioprobes, Italy & $2010(19)$ \\
\hline \multirow[t]{2}{*}{ Egypt } & 2428 & 84.3 (NS) & In-house enzyme immunoassay & $2006(20)$ \\
\hline & 116 & $58.6(\operatorname{IgG})$ & Genelabs Diagnostics, Singapore & $2011(21)$ \\
\hline \multirow[t]{2}{*}{ France } & 315 & 7.74 (IgG); o (IgM) & Wantai, China & $2014(22)$ \\
\hline & $263^{\mathrm{a}}$ & 5.6 (IgG and IgM) & Abbott Laboratories, United States of America & $1993(23)$ \\
\hline Tunisia & 404 & 12.1 (IgG); o (IgM) & Globe Diagnostics SRL, Italy & $2011(24)$ \\
\hline Greece & $98^{\mathrm{b}}$ & 2 (NS) & Abbott Laboratories, United States of America & $1996(25)$ \\
\hline
\end{tabular}

NS: not specified.

aPregnant women born outside France.

${ }^{b}$ Pregnant Albanian refugees. 
public health measures for decreasing hepatitis $\mathrm{E}$ virus infections and related mortality and morbidity.

Good hygiene and sanitation conditions are important factors in maintaining the low prevalence rate of hepatitis $\mathrm{E}$ and must continue to improve. However, the Syrian conflict has displaced millions of Syrians from Syria to neighbouring countries, including Lebanon which hosts about 1.5 million Syrian refugees. Because of their unfavourable living conditions, displaced populations and refugees are at higher risk of hepatitis $\mathrm{E}$ virus infection and large outbreaks of this virus in such populations have been documented, for example in Darfur, Sudan (32). Maintaining the low prevalence hepatitis $\mathrm{E}$ virus in Lebanon in these new circumstances requires more vigilance and careful epidemiological monitoring of the refugee population at risk.

It is important to note that the different serological tests available for hepatitis $\mathrm{E}$ virus detection show considerable discrepancies in their results (33-37). Indeed, significantly different IgG seroprevalence values have been reported in the same populations from the same geographical areas using different serological assays $(3.6 \%$ and $16.2 \%$ in United Kingdom blood donors and $10.9 \%$ and $31.3 \%$ in French kidney and liver transplant recipients) $(35,37)$. We used only one commercially available assay to test sera. It is possible therefore that our results may not reflect the actual prevalence of anti-hepatitis E virus IgG antibodies in our sample of pregnant woman. In addition, we did not check anti-hepatitis E virus IgM antibodies or the serum levels of liver enzymes such as alanine aminotransferase and aspartate aminotransferase which are important markers of an acute recent hepatitis $\mathrm{E}$ virus infection (11,13). We may therefore have missed possible subclinical asymptomatic cases of ongoing acute hepatitis E virus infection.

Since our study included only pregnant women from four health facilities in Tripoli in the north of Lebanon, our results may not reflect the actual prevalence of hepatitis $\mathrm{E}$ virus in the North governorate or at the national level. Moreover, in Lebanon, pregnant women are not all covered by the health system; therefore, we may have missed poorer women who are usually at higher risk of hepatitis $\mathrm{E}$ virus infection but who never or rarely seek antenatal care. Future studies that sample a wider range of the population would be more helpful.

Our results suggest that hepatitis $\mathrm{E}$ virus does not need to be included in routine prenatal screening programmes. However, further studies among both pregnant women and other populations in different areas of the country are needed to clarify the prevalence and epidemiological trends of hepatitis E virus infection in Lebanon.

\section{Acknowledgements}

We thank all the participants and the health staff who collected the data and blood samples. We also thank Mr Majdeddine Mouzawak and Mr Taha Abdou for their technical assistance.

Funding: This work was supported by the Lebanese University.

Competing interests: None declared.

\section{Séroprévalence du virus de l'hépatite $\mathrm{E}$ chez les femmes enceintes au nord du Liban Résumé}

Contexte: Le virus de l'hépatite $\mathrm{E}$ constitue la principale cause d'hépatite aiguë dans le monde. L'infection est particulièrement grave pour les femmes enceintes, chez qui le taux de mortalité peut atteindre $25 \%$. La prévalence du virus de l'hépatite $\mathrm{E}$ chez les femmes enceintes au Liban n'est pas connue.

Objectifs : La présente étude visait à étudier la séroprévalence de l'infection par le virus de l'hépatite $\mathrm{E}$ dans un échantillon de femmes enceintes au nord du Liban.

Méthodes: Au total, 450 femmes enceintes de Tripoli, dans le nord du Liban, ont été incluses dans l'étude. Des prélèvements sériques ont été effectués à la recherche d'anticorps de la classe des IgG dirigés contre le virus de l'hépatite E en recourant à la méthode ELISA. Des informations ont été recueillies sur les caractéristiques sociodémographiques de ces femmes et leurs facteurs de risque d'infection par le virus de l'hépatite E (source d'eau de boisson, transfusion sanguine et contact avec les animaux).

Résultats : Une seule femme a été testée positive au virus de l'hépatite E, pour une prévalence de 0,22\%. Ses conditions de vie, son statut socio-économique et son niveau d'études étaient bons, et elle n'avait indiqué aucune exposition à aucun facteur de risque associé à l'infection par le virus de l'hépatite E. La plupart des femmes (87,3\%) avaient un niveau de revenu moyen à élevé, 47,1 \% d'entre elles avaient reçues une formation universitaire et 64,9\% buvaient de l'eau en bouteille. Seule une faible proportion d'entre elles étaient exposées à des facteurs de risque d'infection par le virus de l'hépatite $\mathrm{E}: 14,7 \%$ d'entre elles avaient un contact direct avec des animaux et 3,8 \% avaient reçu une transfusion sanguine.

Conclusion : La prévalence de l'infection par le virus de l'hépatite E dans l'échantillon était faible (0,22 \%). Cependant, d'autres études épidémiologiques au sein d'autres groupes de population sont nécessaires pour déterminer la prévalence du virus de l'hépatite E à l'échelle nationale au Liban. 


$$
\text { الانتشار المصليّ لفيروس التهاب الكبد E بين الحوامل في شحال لبنان بشار إسماعيل، صفاء خضر، مروان عثمان، حسان ملاط ، فؤ اد دبوسي، منذر حمزة }
$$

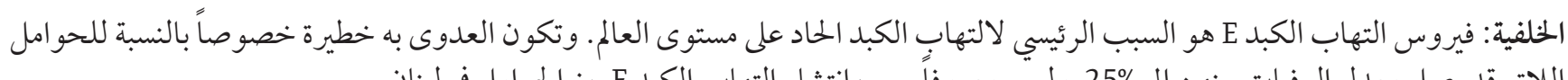

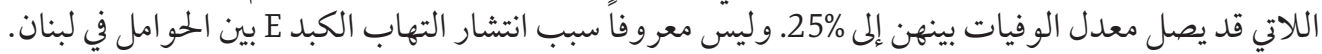

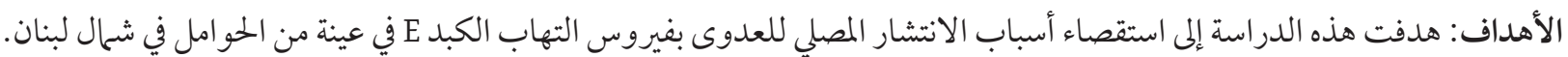

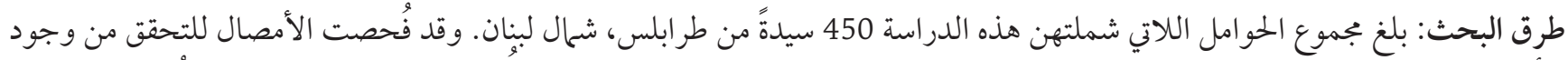

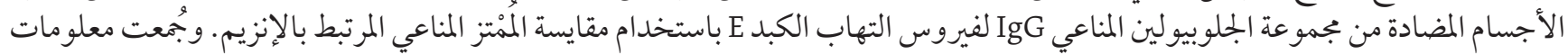

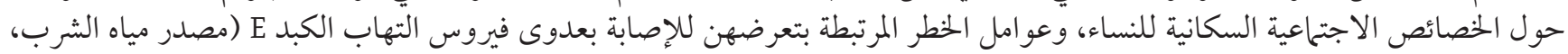
ونقل الدم، ومخالطة الحيوانات).

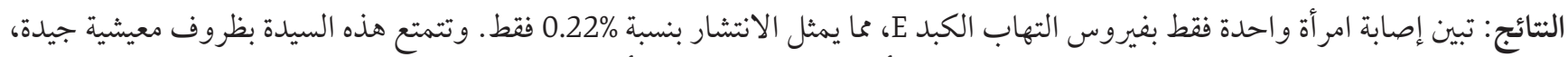

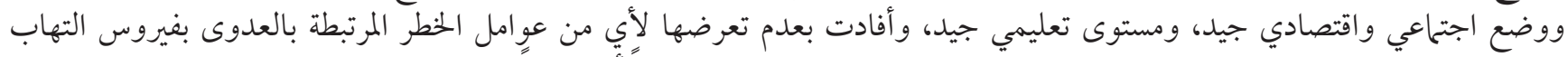

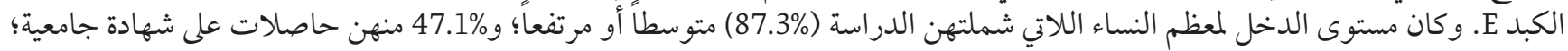

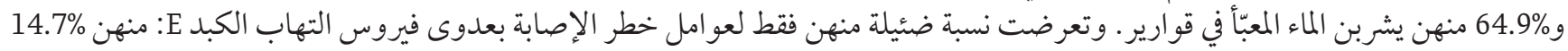

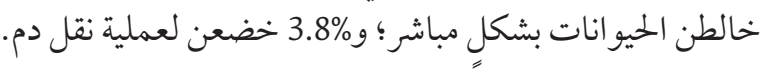

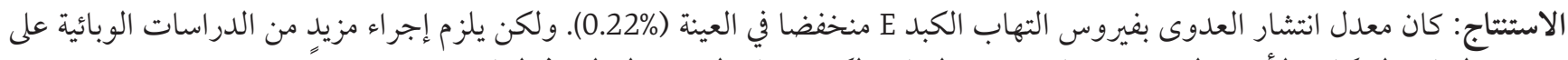

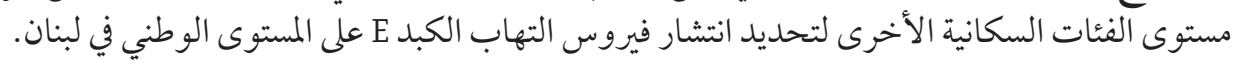

\section{References}

1. $\quad$ Kamar N, Bendall R, Legrand-Abravanel F, Xia NS, Ijaz S, Izopet J, et al. Hepatitis E. Lancet. 2012;379(9835):2477-88. https://doi. org/10.1016/S0140-6736(11)61849-7

2. Hepatitis E. Key facts. Geneva: World Health Organization; 2018 (https://www.who.int/news-room/fact-sheets/detail/hepatitis-e, accessed 1 July 2019).

3. Lu L, Li C, Hagedorn CH. Phylogenetic analysis of global hepatitis E virus sequences: genetic diversity, subtypes and zoonosis. Rev Med Virol. 2006;16(1):5-36. https://doi.org/10.1002/rmv.482

4. Perez-Gracia MT, Suay B, Mateos-Lindemann ML. Hepatitis E: an emerging disease. Infect Genet Evol. 2014;22:40-59. https://doi. org/10.1016/j.meegid.2014.01.002

5. Dalton HR, Bendall R, Ijaz S, Banks M. Hepatitis E: an emerging infection in developed countries. Lancet Infect Dis. 2008;8(11):698-709. https://doi.org/10.1016/S1473-3099(08)70255-X

6. Sridhar S, Lau SK, Woo PC. Hepatitis E: a disease of reemerging importance. J Formos Med Assoc. 2015;114(8):681-90. https://doi. org/10.1016/j.jfma.2015.02.003

7. Ahmed A, Ali IA, Ghazal H, Fazili J, Nusrat S. Mystery of hepatitis E virus: recent advances in its diagnosis and management. Int J Hepatol. 2015;2015:872431. https://doi.org/10.1155/2015/872431

8. Marano G, Vaglio S, Pupella S, Facco G, Bianchi M, Calizzani G, et al. Hepatitis E: an old infection with new implications. Blood transfus. 2015;13(1):6-17. https://doi.org/10.2450/2014.0063-14

9. Aggarwal R. Clinical presentation of hepatitis E. Virus Res. 2011;161(1):15-22. https://doi.org/10.1016/j.virusres.2011.03.017

10. Kumar A, Beniwal M, Kar P, Sharma JB, Murthy NS. Hepatitis E in pregnancy. Int J Gynaecol Obstet. 2004;85(3):240-4. https:// doi.org/10.1016/j.ijgo.2003.11.018

11. Krain LJ, Nelson KE, Labrique AB. Host immune status and response to hepatitis E virus infection. Clin Microbiol Rev. 2014;27(1):139-65. https://doi.org/10.1128/CMR.00062-13

12. Rein DB, Stevens GA, Theaker J, Wittenborn JS, Wiersma ST. The global burden of hepatitis E virus genotypes 1 and 2 in 2005. Hepatology. 2012;55(4):988-97. https://doi.org/10.1002/hep.25505.

13. Hoofnagle JH, Nelson KE, Purcell RH. Hepatitis E. N Engl J Med. 2012;367(13):1237-44. https://doi.org/10.1056/NEJMra1204512

14. Irani Hakime N, Feghali Haibeh R. Virus de l'hépatite E: détection des anticorps dans une population de donneurs de sang au Liban [Hepatitis E virus: detection of antibodies in blood donors in Lebanon]. J Med Liban. 1998;46(2):60-2.

15. Cevrioglu AS, Altindis M, Tanir HM, Aksoy F. Investigation of the incidence of hepatitis E virus among pregnant women in Turkey. J Obstet Gynaecol Res. 2004;30(1):48-52. https://doi.org/10.1111/j.1341-8076.2004.00155.X

16. Oncu S, Oncu S, Okyay P, Ertug S, Sakarya S. Prevalence and risk factors for HEV infection in pregnant women. Med Sci Monit. 2006;12(1):CR36-9. 
17. Suarez Gonzalez A, Solis Sanchez G, Otero Guerra L, Viejo De La Guerra G, Alvarez Navascues C, Garcia Lopez R. Prevalencia de inmunidad frente a los virus de la hepatitis en gestantes del Área Sanitaria de Gijon [Prevalence of immunity to hepatitis viruses in pregnant women from the health area of Gijon (Spain)]. Gastroenterol Hepatol. 2004;27(6):347-52. https://doi. org/10.1157/13062888

18. Buti M, Dominguez A, Plans P, Jardi R, Rodriguez-Frias F, Girones R, et al. Infrequent detection of hepatitis E virus RNA in pregnant women with hepatitis E virus antibodies in Spain. Liver Int. 2010;30(10):1549-51. https://doi.org/10.1111/j.14783231.2010.02304.X

19. Lindemann ML, Gabilondo G, Romero B, de la Maza OM, Perez-Gracia MT. Low prevalence of hepatitis E infection among pregnant women in Madrid, Spain. J Med Virol. 2010;82(10):1666-8. https://doi.org/10.1002/jmv.21840

20. Stoszek SK, Abdel-Hamid M, Saleh DA, El Kafrawy S, Narooz S, Hawash Y, et al. High prevalence of hepatitis E antibodies in pregnant Egyptian women. Trans R Soc Trop Med Hyg. 2006;100(2):95-101. https://doi.org/10.1016/j.trstmh.2004.12.005

21. Gad YZ, Mousa N, Shams M, Elewa A. Seroprevalence of subclinical HEV infection in asymptomatic, apparently healthy, pregnant women in Dakahlya Governorate, Egypt. Asian J Transfus Sci. 2011;5(2):136-9. https://doi.org/10.4103/0973-6247.83238

22. Renou C, Gobert V, Locher C, Moumen A, Timbely O, Savary J, et al. Prospective study of hepatitis E virus infection among pregnant women in France. Virol J. 2014;11:68. https://doi.org/10.1186/1743-422X-11-68

23. Ranger-Rogez S, Denis F, Udin L. Seroprevalence of hepatitis E among pregnant foreign residents in France. Lancet. 1993;342(8877):998-9. https://doi.org/10.1016/0140-6736(93)92050-4

24. Hannachi N, Hidar S, Harrabi I, Mhalla S, Marzouk M, Ghzel H, et al. Seroprevalence et facteurs de risque de l'hépatite virale E chez la femme enceinte dans le centre tunisien [Seroprevalence and risk factors of hepatitis E among pregnant women in central Tunisia]. Pathol Biol (Paris). 2011;59(5):e115-8. https://doi.org/10.1016/j.patbio.2009.06.004

25. Malamitsi-Puchner A, Papacharitonos S, Sotos D, Tzala L, Psichogiou M, Hatzakis A, et al. Prevalence study of different hepatitis markers among pregnant Albanian refugees in Greece. Eur J Epidemiol. 1996;12(3):297-301. https://doi.org/10.1007/bfoo145420

26. Yazbek S, Kreidieh K, Ramia S. Hepatitis E virus in the countries of the Middle East and North Africa region: an awareness of an infectious threat to blood safety. Infection. 2016;44(1):11-22. https://doi.org/10.1007/s15010-015-0807-5

27. Redlinger T, O'Rourke K, Nickey L, Martinez G. Elevated hepatitis A and E seroprevalence rates in a Texas/Mexico border community. Tex Med. 1998;94(5):68-71.

28. Trinta KS, Liberto MI, de Paula VS, Yoshida CF, Gaspar AM. Hepatitis E virus infection in selected Brazilian populations. Mem Inst Oswaldo Cruz. 2001;96(1):25-9. https://doi.org/10.1590/s0074-02762001000100004

29. Pujol FH, Favorov MO, Marcano T, Este JA, Magris M, Liprandi F, et al. Prevalence of antibodies against hepatitis E virus among urban and rural populations in Venezuela. J Med Virol. 1994;42(3):234-6. https://doi.org/10.1002/jmv.1890420305

30. Rostamzadeh Khameneh Z, Sepehrvand N, Khalkhali HR. Seroprevalence of hepatitis E among pregnant women in Urmia, Iran. Hepat Mon. 2013;13(11):e10931.

31. Bharadia V, Singh N, Nijhawan S, Rai R. 36 prevalence of hepatitis E virus infection among pregnant women in Rajasthan. J Clin Exp Hepatol. 2011;1(2):149. https://doi.org/10.1016/S0973-6883(11)60173-4

32. Guthmann JP, Klovstad H, Boccia D, Hamid N, Pinoges L, Nizou JY, et al. A large outbreak of hepatitis E among a displaced population in Darfur, Sudan, 2004: the role of water treatment methods. Clin Infect Dis. 2006;42(12):1685-91. https://doi. org/10.1086/504321

33. Bendall R, Ellis V, Ijaz S, Thurairajah P, Dalton HR. Serological response to hepatitis E virus genotype 3 infection: IgG quantitation, avidity, and IgM response. J Med Virol. 2008;80(1):95-101. https://doi.org/10.1002/jmv.21033

34. Abravanel F, Mansuy JM, Huynh A, Kamar N, Alric L, Peron JM, et al. Low risk of hepatitis E virus reactivation after hematopoietic stem cell transplantation. J Clin Virol. 2012;54(2):152-5. https://doi.org/10.1016/j.jcv.2012.02.015.

35. Rossi-Tamisier M, Moal V, Gerolami R, Colson P. Discrepancy between anti-hepatitis E virus immunoglobulin G prevalence assessed by two assays in kidney and liver transplant recipients. J Clin Virol. 2013;56(1):62-4. https://doi.org/10.1016/j.jcv.2012.09.010

36. Avellon A, Morago L, Garcia-Galera del Carmen M, Munoz M, Echevarria JM. Comparative sensitivity of commercial tests for hepatitis E genotype 3 virus antibody detection. J Med Virol. 2015;87(11):1934-9. https://doi.org/10.1002/jmv.24251

37. Bendall R, Ellis V, Ijaz S, Ali R, Dalton H. A comparison of two commercially available anti-HEV IgG kits and a re-evaluation of anti-HEV IgG seroprevalence data in developed countries. J Med Virol. 2010;82(5):799-805. https://doi.org/10.1002/jmv.21656 